\title{
Ichthyosaur embryos outside the mother body: not due to carcass explosion but to carcass implosion
}

\author{
A. J. van Loon
}

Received: 14 November 2012 / Accepted: 12 December 2012 /Published online: 24 January 2013

(C) The Author(s) 2013. This article is published with open access at Springerlink.com

\begin{abstract}
Some well-preserved ichthyosaurs found in the Early Jurassic Posidonienschiefer Formation at Holzmaden (Germany) have puzzled palaeontologists for a long time: their skeletons are exceptionally well preserved and their bones are almost all in situ, but the bones of their embryos are scattered, partly beyond the body limits of the mother. This has been explained initially by bottom currents and later by a displacement of already disarticulated embryos during the expulsion of putrefaction gases through the disrupted body wall of the mother. It was postulated recently that this latter hypothesis is not tenable. It is argued here that both hypotheses are not tenable in their original form, but that carcass implosion may explain the various enigmatic features.
\end{abstract}

Keywords Ichthyosaurs · Posidonienschiefer Formation · Carcass implosion $\cdot$ Early Jurassic

\section{Introduction}

In a contribution by Reisdorf et al. (2012) to the special issue of this journal devoted to taphonomic processes in terrestrial and marine environments (Wuttke and Reisdorf 2012), the postmortem fate of large lung-breathing marine vertebrates was dealt with. One of the aspects in this work that are of special interest for palaeontologists is the analysis of the event(s) that has led to the relatively common occurrence of (almost) intact skeletons of female ichthyosaurs, with bones of foetuses scattered nearby but outside the mother skeleton. As an example, Reisdorf et al. (2012)

\section{A. J. van Loon $(\square)$}

Geological Institute, Adam Miczkiewicz University,

Maków Polnych 16,

61-606 Poznan, Poland

e-mail: tvanloon@amu.edu.pl mention a skeleton of a Stenopterygius specimen from the Posidonienschiefer (= Posidonia Shale) Formation at Holzmaden (Germany), stored at the Staatliches Museum für Naturkunde Stuttgart as number SMNS 50007 (Fig. 1).

The, at first sight, abnormal position of the inarticulate bones of several foetuses outside the body, at both the dorsal and the ventral sides, of the pregnant ichthyosaur (as proven by the presence of some more foetuses inside the skeleton) has drawn the attention of palaeontologists for more than a century. Their position was explained at the time (Osborn 1905) as a result of the activity of bottom currents, but later a more spectacular origin ('carcass explosion') has been proposed (Keller 1976; Martill 1993), viz. an eruption caused by an increasing pressure of putrefaction gases inside the decomposing body (resulting from microbial activity), strong enough to blow the embryos-together with intestines, etc.- - out of the mother's body, but not strong enough to destroy the still articulated skeleton of the adult. Böttger (1990) detailed this further by ascribing the foetus bone positions to the displacement of the already disarticulated foetus embryos during the expulsion of putrefaction gases through the ruptured body wall of the mother. As Reisdorf et al. (2012) state: "In spite of the lack of (direct) evidence for these processes, these ideas have never been questioned".

\section{Putrefaction gases hypothesis under fire}

Reisdorf et al. (2012) attack the above putrefaction gases hypothesis, and come to the conclusion that this hypothesis is not tenable, at least not for the fossils preserved in the Toarcian (Early Jurassic) Posidonienschiefer Formation. Unfortunately, they do not explicitly state what other process(es) might be responsible for the foetus bones outside the mother skeleton, but they seem implicitly to adhere to the original bottom-current hypothesis of Osborn (1905). Why the 
Fig. 1 Example of a female Stenopterygius from the Posidonienschiefer Formation at Holzmaden (specimen SMNS 50007; image by courtesy of Staatliches Museum für Naturkunde Stuttgart) with several embryos still inside the skeleton of the mother body, but also with several disarticulated embryo bones outside the ventral part of the body, possibly expulsed by turbulent water that originated from carcass implosion after a scavenger had eaten away part of the flesh of the mother body at the ventral side

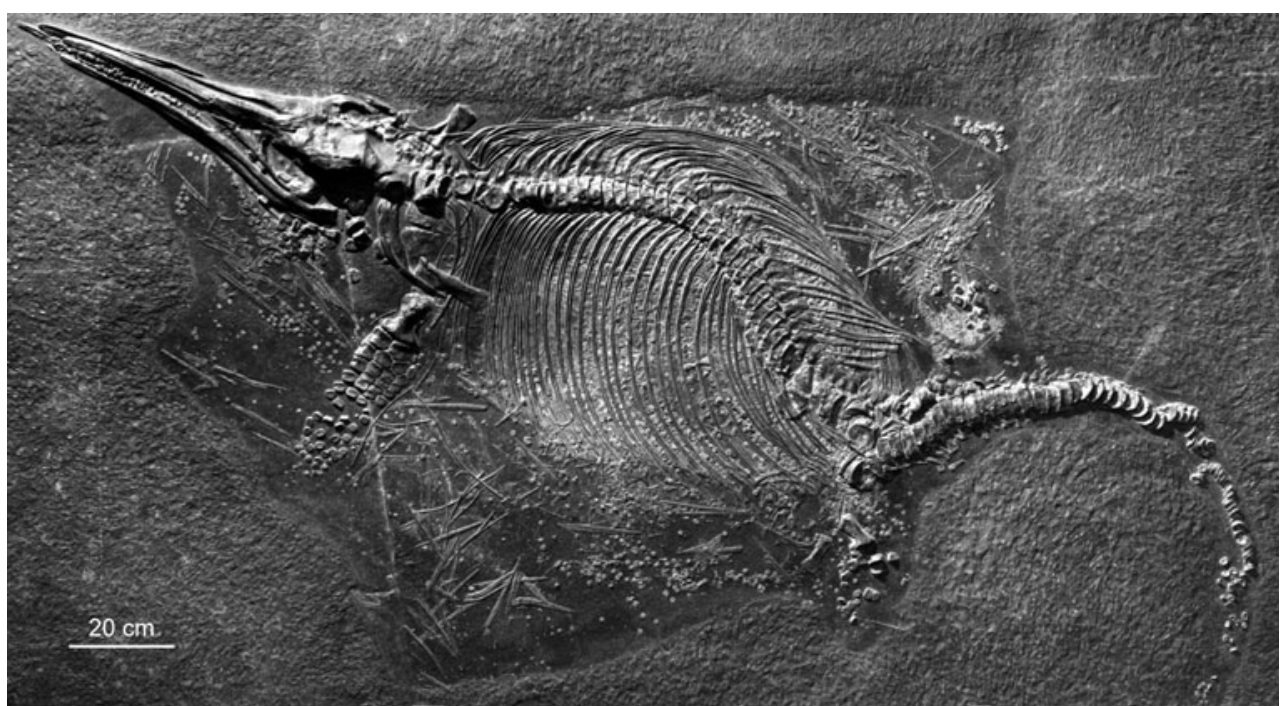

advocates of the putrefaction-gas hypothesis did not agree with the bottom current hypothesis, is not discussed.

These authors come to their conclusion based on what seem to be sound physical data. For the purpose, they carried out (1) a literature study on the depositional conditions of the Posidonienschiefer Formation, a black shale that has yielded numerous well-preserved fossils, including $>3,000$ specimens of marine vertebrates, among which numerous ichthyosaurs; and (2) they evaluated the most probable characteristics of ichthyosaurs.

\section{The Posidonienschiefer conditions}

The Posidonienschiefer Formation was deposited at 50-150 m depth (Röhl et al. 2001) and consists of black shales, which is attributed to a stagnant basin (Pompeckj 1901 and many others). The shales are finely laminated and lack bioturbation, which points to oxygen-deficient conditions at the bottom; this might explain why the skeletons of so many ichthyosaur and other marine vertebrates have been found (almost) completely undisturbed: the bottom conditions were-at least most of the time - unfavourable (if not hostile) for potential scavengers.

The bottom, which was 50-150 m deep (important for the attack by Reisdorf et al. (2012) on the putrefaction gases hypothesis), and the topmost decimetres of the bottom sediments would, according to some authors, have been 'soupy' during some intervals, probably nearly fluid (Hofmann 1958; Martill 1993). This would have enabled ichthyosaurs and other vertebrates that had sank to the bottom to become embedded in the bottom sediment (Schimmelmann et al. 1994). Smith and Wuttke (2012), however, are critical concerning this way of embedding, and - as will be indicated below-their critical evaluation is justified.

Seilacher (1982) had already noticed that organic-rich, muddy sediments such as the Posidonienschiefer tend to accumulate under tranquil conditions, but Reisdorf et al. (2012) argue-like several others (Kaufmann 1981; Röhl and Schmid-Röhl 2005; Schieber et al. 2007) - that some evidence of weak to moderate currents indicates changes in the depositional environment. These currents might have eroded some of the smaller bones, although — as Reisdorf et al. (2012) agree - the cohesive bottom sediments would have required a relatively strong current, depending on the degree of the sediment's consolidation. The resistance against erosion might, however, be increased by bacteria/particle interaction (cf. Widdel 1988; Black et al. 2003). Moreover, the high sedimentation rate of $4 \mathrm{~mm}$ per 1,000 years (for compacted sediments) might have favoured dewatering of the originally soupy substrate. Under such conditions, Reisdorf et al. (2012) follow authors (e.g. Blob 1997; Boaz and Behrenmeier 1976; Lam et al. 2003) who argue that bones of the thorax and the appendages begin to move at velocities "as low as $0.2-0.4 \mathrm{~m} / \mathrm{s}$ ". Thus, ichthyosaur bones could have been transported by bottom currents, but — according to Reisdorf et al. (2012) — without eroding mud.

Also important for the putrefaction gases hypothesis is the temperature, as putrefaction rates decelerate with decreasing temperature (Bonhotal et al. 2006; Dickson et al. 2011; Robinson et al. 1953). The water temperature at the bottom of the epeiric sea in which the Posidonienschiefer accumulated is not known, but the surface-water temperature has been estimated to have fluctuated between 25 and $30{ }^{\circ} \mathrm{C}$ (Röhl et al. 2001). Since the water depth (50-150 m) was limited, the bottom-water temperature was probably high enough (probably even favourable) to allow putrefaction gases to develop.

Ichthyosaur characteristics

Ichthyosaurs probably lived spread over all oceans (McGowan 1978) and numerous well-preserved specimens have provided 
detailed information about their anatomy. The absence of ossified tracheas indicates that they must have been able to dive to great depth, even exceeding $500 \mathrm{~m}$ (Humphries and Ruxton 2002; McGowan and Motani 2003); more or less ossified trachea limit the diving depth (Mason and MacDonald 1986; Tarasoff and Kooyman 1973;). Ichthyosaurs must thus have been able to dive to the bottom of the 'Posidonienschiefer Sea', in spite of the fact that their bodies had a lower density than seawater (McGowan 1992; Taylor 1987, 2001).

Because of this low density, it has hitherto been presumed that dead ichthyosaurs drifted for some time at the sea surface, during which time their preservation quality decreased (Fröbisch et al. 2006; Long et al. 2006; Martill 1986) and putrefaction gases developed. Either by leakage of these gases, or by bursting (Cruickshank and Fordyce 2002; Kuhn-Schyder 1974)_commonly called 'carcass explosion'- they eventually sank to the bottom.

Carcass explosion physically impossible

On the basis of the above data and considerations, Reisdorf et al. (2012) state that they can falsify the putrefaction gases hypothesis. Their main argument is the presumed impossibility of a carcass explosion at the bottom of the Posidonienschiefer Sea. They deduce this impossibility from measurements (at the Institute of Forensic Medicine in Frankfurt; Bux et al. 2004) of the pressure that built up in 100 human corpses. The intra-abdominal pressures did not exceed 0.035 bar $(3.5 \mathrm{kPa})$. Even though the pressure became twice as high in goat corpses, this is far too low to allow carcass explosion at a depth of tens of metres, as the above values are equivalent to the pressure by a water column of only 35 and $79 \mathrm{~cm}$. For a carcass explosion at $50-150 \mathrm{~m}$ depth, the pressure of the putrefaction gases in the ichthyosaur bodies should have been 5-15 bar (0.5-1.5 $\mathrm{MPa})$, which seems physically impossible.

As alternatives, Reisdorf et al. (2012) present two models, in which the burial depth of the bodies (0-100\% covered by sediment) plays an important role. In this context, they also build on the assumption that the palaeoenvironment at the time was neither entirely nor continuously anoxic (cf. Kauffman 1981; Röhl et al. 2001).

\section{Questionable aspects}

Obviously, Reisdorf et al. (2012) are correct in their calculations that indicate that a natural carcass explosion at the bottom of the Posidonienschiefer Sea was unlikely or even - and much more probable-physically impossible. There are, however, quite a few points to which they do not give due attention, or where their argumentation is inconsistent. This does not imply by definition that their hypothesis that carcass explosions cannot account for the ichthyosaur with embryos outside the mother body is wrong, but their evaluation is not complete and does not fully explain some of the features. This is fairly surprising, since they seem so close to a much more likely explanation, that will be dealt with below. This requires first, however, a discussion of their assumptions regarding the depositional environment, and in the second place their deductions with respect to the (im)possibility of carcass explosions at the bottom of the Posidonienschiefer Sea.

\section{Discussion of the depositional environment}

Reisdorf et al. (2012) argue that the sea was largely anoxic, which was favourable for the preservation of bodies of marine vertebrates; such bodies must have been a potential free meal for scavengers, but no traces of scavengers are known from the formation. This might, indeed, indicate an anoxic environment. Some remarks by Ronald Böttcher (personal communication, 27 November 2012) are, however, relevant in this context. He mentions that no signs of vertebrate scavengers have been found in the Posidonienschiefer, and that invertebrate scavengers like crabs must be considered incapable of eating away large parts of an ichthyosaur, and all reptile and fish fossils show simple teeth with a rounded cross-section. It cannot be fully excluded that that some types of sharks (Hexanchoida) have been present and that they were scavengers, but no remnants have been found in the Posidonienschiefer; moreover, the first Hexanchoidia, which indeed appeared earlier (Sinemurian) became common only after the Toarcian Posidonienschiefer, viz. in the Late Jurassic. Böttcher (personal communication, 6 December 2012) also mentions that benthic organisms must have been far too small to open the body of a dead ichthyosaur.

This apparent absence of scavengers may, at first sight, be a strong argument in favour of a continuously anoxic environment, but this is questionable. Many basins have, in the course of their existence, known anoxic phases without (almost) any life; yet, higher life forms were commonly abundant both before and after such anoxic intervals. This implies that such life must have survived, possibly where the conditions were locally still bearable. A change from anoxic to oxic was commonly accompanied by the remigration of life. This may also have happened in the Posidonienschiefer Sea: even short intervals of oxic conditions may have paved the way for large scavengers; that these scavengers left no trace in the Posidonienschiefer Formation may be a consequence of their limited number because the oxic intervals had a short duration.

Where it fits well in their hypothesis, Reisdorf et al. (2012) indeed mention that the environment was neither 
entirely nor continuously anoxic. This latter situation is probable, indeed, but this requires that a hypothesis about the conditions prevailing when the ichthyosaurs sank to the bottom must be made clear (which Reisdorf et al. 2012 do not). As will be shown below, this is, however, important for a reconstruction of the sequence of processes that led to the enigmatic position of the embryos.

Another point that is insufficiently made clear by Reisdorf et al. (2012) is the character of the bottom. They assume a 'soupy' bottom sediment, so that the carcass of an ichthyosaur could easily sink down into it and become embedded. On the other hand, however, they consider the bottom — exactly at the time when needed - consolidated enough to prevent mud from being eroded, also at a time that the ichthyosaur skeleton is still so little embedded that bones could be transported by bottom currents.

These two conditions are mutually inconsistent: if the body sediment was soupy enough to make the ichthyosaur become embedded, it cannot have become consolidated enough within a short time span to prevent erosion. It is known from (sub)recent 'soupy' muddy sediments that objects do not sink down into them (not even empty shells with a considerably higher density); even after several centuries, such water-saturated sediments lack consistency and - when a handful is taken - they flow down between one's fingers (Van Loon and Wiggers 1976). Moreover, embedding of an object, not in the form of becoming covered by younger sediments but by sinking down into the substrate, requires a to-and-fro movement by wave action (this is the same process that may cause shipwrecks in shallow seas to become embedded in the sea bottom in a short time). It seems, however, that the bottom of the Posidonienschiefer Sea, with a depth of 50-150 m, cannot have been affected by heavy storms that made so many carcasses dig a hole for themselves so frequently.

Also, in the context of a soupy substrate, the remark by Reisdorf et al. (2012) that dewatering of the sediment was facilitated by the "low net sedimentation rate of $4 \mathrm{~mm} /$ 1,000 years" is important. Such a low sedimentation rate does not imply changing conditions; consequently there is no reason to assume rapid dewatering of the uppermost decimetres of sediment: such dewatering results from the weight of the sedimentary overburden, which was, according to their own arguments, negligible for thousands of years. It seems, therefore, that, if bottom currents would have played a role in the transport of the embryo bones, they must have occurred while the bottom sediment was still soupy. This is inconsistent with their argument that transport of the embryo bones took place when the sedimentary surface was consolidated.

As mentioned above, Reisdorf et al. (2012) do not explicitly mention that the position of the embryo bones just outside the mother body is due to current activity, but they seem to adhere to this theory implicitly. It is difficult, however, to understand how bottom currents could create such a position of the bones. Considering the non-erosional character of the finely laminated muds, the currents must have been slow. At such a depth in a stagnant-water basin, few types of currents tend to occur. One type is constituted by mass flows, but the sediments do not show any signs of such event currents. The other type are currents that follow long-lived patterns, such as contour current (Rebesco and Camerlenghi 2008). It seems too much of a coincidence that such bottom currents in the Posidonienschiefer Sea were strong enough to erode and transport the bones of the embryos (but not those of the mother animal!), to lose their transport capacity only a few centimetres to a few decimetres away from the mother's body. Obviously, in the course of geological times, such a situation can occur, but it seems statistically not realistic to assume that this happened so many times. Moreover, the specimen depicted by Reisdorf et al. (2012) shows foetus bones at both the dorsal and the ventral side of the mother animal, which cannot be explained by a steady (unidirectional) current. In addition, many of the embryo bones must originally have been covered by a much larger bone of the mother. How did such bones escape if the bones of the adult are still in place?

\section{Discussion of the carcass-explosion conditions}

With respect to the carcass explosions that would not have been possible at the bottom of the Posidonienschiefer Sea, Reisdorf et al. (2012) are also not consistent in their argumentation. They mention that, in shallow water at temperatures above $4{ }^{\circ} \mathrm{C}$, "it is very likely that putrefaction gases would cause carcasses to surface and drift", if not covered by sediment (cf. Moreno et al 1992; Petrik et al. 2004), but they also mention that "in marine environments, recent cetaceans and human carcasses may rise from water depths up to $50 \mathrm{~m}$, but never from below $100 \mathrm{~m}$ " (cf. Tomita 1975; Tønnessen and Johnsen 1982). This implies that the depth of the Posidonienschiefer Sea $(50-150 \mathrm{~m})$ did not, at least not always, exclude rising from the bottom!

It is, although somewhat outside this context, also hard to understand why Reisdorf et al. (2012) come to the conclusion that the ichthyosaur remains might be a proxy for sealevel fluctuations. They come to this conclusion on the basis of an analysis of disarticulated skeletons (they presume that the articulated skeletons immediately sank to the bottom, and that adhesion and sediment weight prevented the lifting due to putrefaction that they elsewhere rule out!). Disarticulated skeletons would be found mainly in sediments deposited during eustatic sea-level rise, whereas isolated bones would be found in sediments deposited during eustatic sealevel fall. The reason would be that, during sea-level fall, the hydrostatic pressure would be so low that putrefaction gases 
could develop, so that the carcasses surfaced, became scavenged, and sank back as isolated bones. Although it cannot be fully excluded that such a relationship is found (why not in such a long time?), it seems that this relationship cannot have a causal nature.

\section{An alternative interpretation}

It was explained above that several aspects make both the putrefaction gases hypothesis and the bottom current hypothesis unlikely. Two alternative hypotheses are presented here, one of which is as equally unlikely as those mentioned above. This hypothesis is that the bones of embryos had been deposited before the body of the adult sank down, partly covering the embryo bones. In this case, the adult would not be the mother of the embryos. Again, this may occasionally have happened during geological time, but it seems not realistic to assume that this happened so frequently that several examples could be found.

The sequence of events could rather have been the following. A pregnant ichthyosaur was dying and sank, for whatever reason, to the bottom. If she was not yet dead when she reached the bottom, she may have struggled for life. During her struggle, she may have given untimely birth to some of the foetuses (a possibility suggested by Ronald Böttcher, personal communication, 27 November 2012); this is obvious from fossil SMNS 52036 (fig. 2a and plate 6, fig. 5 in Böttcher 1990). This same fossil, however, also shows some foetus skeletons that must have come out of the mother body in another way, i.e. in the same way as in the case of specimen SMNS 50007 (the specimen depicted by Reisdorf et al. (2012), and shown here as Fig. 1).

This brings us to the most likely alternative hypothesis for the presence of foetus bones outside the mother body. If a dead female ichthyosaur sank to the bottom and the water was warm enough, putrefaction gases would start to develop, but the hydrostatic pressure was too high to prevent surfacing of the body (as correctly argued by Reisdorf et al. 2012). This pressure also prevented a carcass explosion. During the short time-spans that the water was not anoxic (see above), large scavengers may have searched the bottom, hunting for food. The dead ichthyosaur would have been a welcome prey, and a scavenger must have started eating from the dead body, most likely at the place where most meat was present and where few bones hampered having a good meal, for instance at the ventral side. Eating through the body in this way, the body wall became thinner, and could at some time no longer resist the pressure exerted on it.

This pressure was, however, in contrast to the putrefaction gases hypothesis in which an overpressure inside the body was assumed, a result of the hydrostatic pressure outside the body, as has been convincingly indicated by
Reisdorf et al. (2012). There was consequently no physical reason for a carcass explosion, but - in spite of the possible presence of putrefaction gases-for a carcass implosion: the pressure of the seawater was so much higher than the pressure inside the ichthyosaur body that it caused the collapse of the body wall that had been partly eaten away. This resulted in a sudden, turbulent inflow of water into the body. An interesting aspect is that the depth of the Posidonienschiefer Sea is not a parameter that significantly influences the possibility of the turbulence inside the ichthyosaur body.

An understandable question is whether an implosion is possible without overpressurised gases. The question is understandable because, in almost every case where people are confronted with an implosion, some gas is responsible. This need not be the case, however, as implosion is a process in which objects are destroyed by collapsing (or being squeezed in) on themselves. Implosion concentrates matter and energy. True implosion usually involves a difference between internal (lower) and external (higher) pressure, or inward and outward forces, that is so large that the structure collapses inward into itself. An example is a submarine being crushed from the outside by the hydrostatic pressure of the surrounding water. This is comparable with the situation of a dead ichthyosaur at the bottom of a sea of $50-150 \mathrm{~m}$ depth, if the animal's body is filled only with putrefaction gases.

The implosion will have had two relevant consequences. A first consequence will have been that the sudden 'implosive' inflow of water into the ichthyosaur's body and the accompanying turbulence will have scared the scavenger that had been eating from the body, so that he will have fled away without disturbing the body any further. The second, more important, consequence will have been that part of the foetuses may have been carried along with the turbulent water to outside the body, where they rapidly came to rest because the relatively small-scale turbulence can hardly have affected the water mass outside the body. Obviously, there is no reason to assume that all foetuses were carried along with the turbulent water to outside the mother body, which explains why some of the foetuses' bones are found outside the body, whereas others are still inside.

The small foetuses that were expulsed from the mother body in several directions may have become exposed to the very weak contour (or other) bottom currents that may have been present. These weak currents had insufficient energy to erode the embryo bodies and carry them away, but they must have been capable of re-arranging the position of the embryo bones after these had decomposed.

It thus seems that Reisdorf et al. (2012) were quite close to the solution of the enigmatic position of the embryos that has puzzled palaeontologists for such a long time. There was, indeed, no carcass explosion because that was-due to the pressure difference within and outside the ichthyosaur 
body - physically impossible. What Reisdorf et al. (2012) did not realise was that this same pressure difference could lead to an implosion.

Acknowledgements I want to thank Dr Sinje Weber, managing editor of this journal, and Monika Bechtold, editorial assistant Environmental Sciences, for helping me publishing this alternative explanation for a long-lived enigma. Dr Roland Böttcher kindly provided me with a copy of his 1990 work on the reproduction biology of ichthyosaurs, helped me with clarification of some problems and drew my attention to some aspects that were insufficiently clear.

Open Access This article is distributed under the terms of the Creative Commons Attribution License which permits any use, distribution, and reproduction in any medium, provided the original author(s) and the source are credited.

\section{References}

Black KS, Peppe C, Gust G (2003) Erodibility of pelagic carbonate ooze in the northeast Atlantic. J Exp Mar Biol Ecol 285-286:143163

Blob RW (1997) Relative hydrodynamic dispersal potentials of softshelled turtle elements: implications for interpreting skeletal sorting in assemblages of non-mammalian terrestrial vertebrates. Palaios 12:151-164

Boaz NT, Behrensmeyer AK (1976) Hominid taphonomy: transport of human skeletal parts in an artificial fluviatile environment. Am J Phys Anthropol 45:53-60

Bonhotal J, Harrison E, Schwarz M (2006) Evaluating pathogen destruction in road kill composting. Biocycle 47:49-51

Böttcher R (1990) Neue Erkenntnisse über die Fortpflanzungsbiologie der Ichthyosaurier. Stuttg Beitr Naturkd B 164:1-51

Bux R, Reisdorf A, Ramsthaler F (2004) Did the Ichthyosaurs explode? - A forensic-medical contribution to the Taphonomy of Ichthyosaurs in Bituminous Shales. Baltik Medico-Legal Association, Abstracts of the 5th BMLA Congress, October 6.-9. 2004, Saint-Petersburg, p 69

Cruickshank ARI, Fordyce RE (2002) A new marine reptile (Sauropterygia) from New Zealand: further evidence for a Late Cretaceous austral radiation of cryptoclidid plesiosaurs. Palaeontol J 45:557-575

Dickson GC, Poulter RTM, Maas EW, Probert PK, Kieser JA (2011) Marine bacterial succession as a potential indicator of postmortem submersion interval. Forensic Sci Int 209:1-10

Fröbisch NB, Sander M, Rieppel O (2006) A new species of Cymbospondylus (Diapsida, Ichthyosauria) from the Middle Triassic of Nevada and a re-evaluation of the skull osteology of the genus. Zool J Linn Soc 147:515-538

Hofmann J (1958) Einbettung und Zerfall der Ichthyosaurier im Lias von Holzmaden. Meyniana 6:10-55

Humphries S, Ruxton GD (2002) Why did some ichthyosaurs have such large eyes? J Exp Biol 205:439-441

Kauffman EG (1981) Ecological reappraisal of the German Posidonienschiefer and the stagnant basin model. In: Gray J, Boucot AJ, Berry WBN (eds) Communities of the Past. Hutchinson Ross, Stroudsburg, pp 311-381

Keller T (1976) Magen- und Darminhalte von Ichthyosauriern des süddeutschen Posidonienschiefers. N Jb Geol Paläont, Mh 5:266-283

Kuhn-Schnyder E (1974) Die Triasfauna der Tessiner Kalkalpen. Neujahrsbl Natforsch Ges Zürich 176:1-119
Lam YM, Pearson OM, Marean CW, Chen X (2003) Bone density studies in zooarchaeology. J Archaeol Sci 30:1701-1708

Long C, Wings O, Xiaohong C, Sander M (2006) Gastroliths in the Triassic Ichthyosaur Panjiangsaurus from China. J Paleontol 80:583-588

Martill DM (1986) The stratigraphic distribution and preservation of fossil vertebrates in the Oxford Clay of England. Mercian Geol 10:161-188

Martill DM (1993) Soupy substrates: a medium for the exceptional preservation of ichthyosaurs of the Posidonia Shale (Lower Jurassic) of Germany. Kaupia - Darmstädter Beitr Natgesch 2:7797

Mason CF, Macdonald SM (1986) Otters. Cambridge University Press, Cambridge

McGowan C (1978) Further evidence for the wide geographical distribution of ichthyosaur taxa (Reptilia: Ichthyosauria). J Paleont $52: 1155-1162$

McGowan C (1992) The ichthyosaurian tail: sharks do not provide an appropriate analogue. Palaeontology 35:555-570

McGowan C, Motani R (2003) Ichthyopterygia. In: Sues H-D (ed) Handbook of Paleoherpetology, Part 8, Verlag Dr. Friedrich Pfeil, München

Moreno P, Benke H, Lutter S (1992) Behaviour of Harbour poiporse (Phocoena phocoena) carcasses in the German Bight: surfacing rate, decomposition and drift routes. In: Bohlken $\mathrm{H}$, Benke $\mathrm{H}$ (eds) Untersuchungen über Bestand, Gesundheitszustand und Wanderungen der Kleinwalpopulationen (Cetacea) in deutschen Gewässern. Unpublished Interim Report, WWF Fachbereich Wattenmeer \& Nordseeschutz und Forschungs- und Technologiezentrum Westküste, Außenstelle der Universität Kiel, Kiel, pp 1-4

Osborn HF (1905) Ichthyosaurs. The evolution of fitness in ichthyosaurs (Fossil wonders of the West). Cent Mag 69:414-422

Petrik MS, Hobischak NR, Anderson GS (2004) Examination of factors surrounding freshwater decomposition in death investigations: a review of body recoveries and coroner cases in British Columbia. Can Soc Forensic Sci J 37:9-17

Pompeckj JF (1901) Der Jura zwischen Regensburg und Regenstauf. Geogn Jahresh 14:139-220

Rebesco M, Camerlenghi A (eds) (2008) Contourites. Devel Sediment 60. Elsevier, Amsterdam

Reisdorf AG, Bux R, Wyler D, Benecke M, Klug C, Maisch MW, Fornaro P, Wetzel A (2012) Float, explode or sink: postmortem fate of lung-breathing marine vertebrates. In: Wuttke M, Reisdorf AG (eds) Taphonomic processes in terrestrial and marine environments. Palaeobio Palaeoenv 92(1):67-81

Robinson RHM, Ingram M, Case RAM, Benstead JG (1953) Whalemeat: bacteriology and hygiene. Department of scientific and industrial research, food investigation. Spec Rep 59:1-56

Röhl H-J, Schmid-Röhl A (2005) Lower Toarcian (Upper Liassic) black shales of the Central European epicontinental basin: a sequence stratigraphic case study from the SW German Posidonia shale. SEPM Soc Sed Geol Spec Publ 82:165-189

Röhl H-J, Schmid-Röhl A, Oschmann W, Frimmel A, Schwark L (2001) Erratum to "The Posidonia Shale (Lower Toarcian) of SW-Germany: an oxygen-depleted ecosystem controlled by sea level and palaeoclimate". Palaeogeogr Palaeoclimatol Palaeoecol 169:273-299

Schieber J, Southard J, Thaisen K (2007) Accretion of mudstone beds from migrating floccule ripples. Science 318:1760-1763

Schimmelmann A, Schuffert JD, Venkatesan MI, Leather J, Lange CB, Baturin GN, Simon A (1994) Biogeochemistry and origin of a phosphoritized coprolite from anoxic sediment of the Santa Barbara Basin. J Sed Res A64:771-777

Seilacher A (1982) Posidonia Shale (Toarcian, S. Germany) - Stagnate basin model revalidated. In: Gallitelli EM (ed) Palaeontology, essential of historical geology. STEM Mucchi, Modena, pp 25-55 
Smith K, Wuttke M (2012) From tree to shining sea: Taphonomy of the arboreal lizard Geiseltaliellus maarius from Messel, Germany. In: Wuttke M, Reisdorf AG (eds) Taphonomic processes in terrestrial and marine environments. Palaeobio Palaeoenv 92(1). doi:10.1007/s12549-011-0064-2

Tarasoff FJ, Kooyman GL (1973) Observations on the anatomy of the river otter, sea otter, and harp seal. - II. The trachea and bronchial tree. Can J Zool 51:163-170

Taylor MA (1987) Reinterpretation of ichthyosaurs swimming and buoyancy. Palaeontology 30:531-535

Taylor MA (2001) Locomotion in Mesozoic Marine Reptiles. In: Briggs DEG, Crowther PR (eds) Palaeobiology II. Blackwell, Oxford, pp 404-407
Tomita K (1975) On putrefactions and floatations of dead bodies under water. Hirosh J Med Sci 24:117-152

Tønnessen JN, Johnsen AO (1982) The History of Modern Whaling. University of California Press, Berkeley

Van Loon AJ, Wiggers AJ (1976) Metasedimentary "graben" and associated structures in the lagoonal Almere Member (Groningen Formation, The Netherlands). Sed Geol 16:237-254

Widdel F (1988) Microbiology and ecology of sulfate- and sulfurreducing bacteria. In: Zehnder ABJ (ed) Biology of Anaerobic Microorganisms. Wiley, New York, pp 469-585

Wuttke M, Reisdorf AG (eds) (2012) Taphonomic processes in terrestrial and marine environments. Palaeobio Palaeoenv 92(1) 